\title{
Az információs társadalom mint kockázattársadalom
}

A cikk rövid történeti áttekintés után meghatározza a kockázat (rizikó) fogalmát, majd ismerteti a kockázattársadalom és információs társadalom elméletét. Míg a korábbi korok emberének a legnagyobb kockázatot elsősorban az előre nem látható természeti események jelentették, addig ma főként a saját maga által létrehozottak fenyegetik. A cikk fő gondolata az, hogy alapvetően nincs különbség az információs és a kockázattársadalom között, mert a kettő lényegében ugyanaz: az ipari utáni társadalom, csak más elnevezéssel, más hangsúlyokkal. Korunkban nemcsak az információ kezelése változott meg, és azáltal a kockázatnak új tartományai is megjelentek, de átalakult a kockázat percepciója is.

\section{Szerzői információ:}

\section{Pintér Róbert}

1999-ben diplomázott az Eötvös Loránd Tudományegyetem szociológia és 2000-ben a politológia szakán, jelenleg ugyanitt a szociológia $\mathrm{PhD}$ fokozat megszerzése elôtt áll. Megalapítása óta (1998) a BME-UNESCO Információs Társadalom- és Trendkutató Központ (ITTK) kutatója, 2001 januárjától a Budapesti Mưszaki és Gazdaságtudományi Egyetem (BMGE) Információ- és Tudásmenedzsment tanszékének tanársegédje, több felsôfokú intézmény óraadó tanára. Fổ kutatási témája az információs társadalom, ezen belül elsốsorban az információs politika-stratégia; az Európai Unió információs fejlődése; a finn információs társadalom; a (média)konvergencia; és az információs társadalom, mint kockázattársadalom.

Így hivatkozzon erre a cikkre:

Pintér Róbert. „Az információs társadalom mint kockázattársadalom”. Információs Társadalom II, 4. szám (2002): 102-117.

$\Longrightarrow$ https://dx.doi.org/10.22503/inftars.II.2002.4.5 $\rightleftharpoons$

A folyóiratban közölt müvek

a Creative Commons Nevezd meg! - Ne add el! - Így add tovább! 4.0

Nemzetközi Licenc feltételeinek megfelelöen használhatók. 
Pintér Róbe r t

Az információs társadalom

mint kockázattársadalom ${ }^{1}$

\section{Bevezetés}

Angliában a repülőgépmotorok biztonsági szabványainak a felülvizsgálatát kezdeményezték az ezredfordulón, mert a lökhajtásos gépek maximum 3,6 kilogramm súlyú vadludakat képesek biztonságosan felaprítani repülés közben. Az utóbbi tíz évben viszont az ennél is kövérebb ludak szaporodtak el, amelyek ugyancsak nagy csapatokban közlekednek a légtérben. A madarak száma és testsúlya a közparki etetések miatt nôtt meg, s irtásuk kisebbfajta zendülést okozna az angol társadalomban. Így aztán a megoldás technológiai: gyorsabban forgó motorok és nagyobb, élesebb lapátok. A megszokott logika ismét diadalt arat: technológiával odázzák el a probléma valódi kezelését. (Kövér ludak fenyegetik a légi közlekedést, 2001)

2001. november közepén különös jelenés tanúi lehettek a kaliforniai Pacific Lumber Company favágói: a dúskeblű földanya jelent meg nekik félmeztelenül és felszólította ôkket, hogy imádják őt: „Én vagyok az istennő, és most minden nő nevében beszélek. Én vagyok a Föld, a teremtés bölcsôje, ágyékom redôi rejtik üdvösségedet. Térdelj le, és imádj engem!” (Ökotantarikus nôi rapperek a faipar ellen, 2001)

Valójában a környezetvédő Dona Nieto kezdeményezésérôl volt szó, a „Meztelen mellekkel a fákért” mozgalomról. A Reuters híre szerint ennek ellenére az egyik favágó térdre rogyott és megcsókolta a földet.

E két hírből is látszik, hogy olyan társadalomban élünk, ahol bár látszólag egyre kisebb a szerepe a természetnek, mégis mindannyian tisztában vagyunk vele - csak jó mélyen elfojtjuk -, hogy „rosszul mennek a dolgaink.”

A természet leigázása úgy tűnik félresikerült. Technológiával, még több technológiával kezeljük azokat a problémákat, amelyeket épp a technológia okozott. Az elmúlt három-négyszáz évben felépítettünk egy olyan társadalmi és gazdasági rendszert - a modern kapitalizmust -, ahol a hatékonyság, a versenyképesség és a jövő gyarmatosítása a túlélés záloga. Kérdés, hogy tud-e ezen a logikán változtatni az új információs korszak, vagy ezt az alapelvet az újfajta termelési és együttélési mód sem tudja felülírni?

Tehát: vajon más-e a hálózati társadalom alaplogikájában és a környezethez való viszonyában, mint a korábbi, ipari korszak? A kérdés megválaszolásához a kockázattársadalom fogalmát fogjuk eszközként felhasználni. (Beck, Ulrich, 1998) 


\section{A kockázat fogalma}

A kockázat viszonylag „új” fogalom, amit a kora-modern társadalmak találtak fel a körülöttük lévő világ és a jövố biztonságosabbá tételéhez. ${ }^{2}$ A rizikó szó eredendôen a tengeri hajózásban jelent meg elôször - mégpedig a földrajzi felfedezések idején, amikor még viszonylag nagy kiterjedtségúek voltak az ismeretlen, nyugat-európai hajós által be nem járt tengerek.

A rizikó eredetileg portugál vagy spanyol szó volt - új területek (térbeli) felfedezését jelentette, ismeretlen vizeken hajózást. Vagyis kezdetben szinte semmi köze sem volt az időhöz, így a Jövőhöz sem. Csak egy folyamatos jelentésmódosulás során kezdték el a fogalmat alkalmazni minden ismeretlenre, mindenre, ami a jövőben bekövetkezhet, mégis valamennyire előre látható, megfogható, kiszámítható. Vagyis lassacskán lett a térre utaló szóból - idôre utaló fogalom.

A tradicionális társadalmakban - így a földrajzi felfedezések korát megelôző Európában is - nem igazán létezett a mai értelemben vett, elterjedt kockázat-fogalom. Az emberek nagy többsége más viszonyban állt a külsô világgal és annak eseményeivel. Azt, hogy mi történik velük és miért, sokkal inkább a szerencsével, az ,istenek akaratával”, a sorssal, varázslattal stb. magyarázták. Olyan világban éltek, ahol a múlt, a tradíciók, a kozmikus erók ismerete sokkal fontosabb volt a túlélésben, mint a jövôbeli események kiszámíthatósága. ${ }^{3}$

A kockázat fogalom használata akkor terjedt el, amikor a társadalom egy jelentôs része számára a túlélés egyre inkább a jövőbeli események kiszámítható ellenôrzésén múlott. A vállalkozónak, a polgárnak a modern kor hajnalán középpontivá vált, hogy kiszámíthatóvá váljon az üzletmenet, hogy racionális módon kalkulálható legyen, mi fog történni a jövôben. Vagyis elsőrendű kérdéssé vált, hogy higgyen a saját elôrelátásában, ügyességében és abban, hogy ezen múlik a sikere. Ezért szüksége volt egy olyan világképre, amely jövố- és nem múltorientált, ahol a jövőre vonatkozó elvárások kalkulációja elképzelhetô. ${ }^{4}$

Az így létrejövő kockázat-fogalomnak a fókuszában az eseményekhez hozzárendelhetố valószínúség és a dolgok kiszámíthatósága áll(t). A vállalkozó tudta, hogy mire, milyen eseményekre számíthat a jövőben és ehhez igazította a cselekvéseit a jelenben. Arra az esetre pedig, ha mégis beütne az igen valószínútlen, megjelent egy új iparág: a biztosítás. „A biztosítás azt a határvonalat jelenti, amelyen belül az emberek kockázatot vállalnak. Mint a kockázat fogalmánál, a biztosítás korszerú formái is a tengerhajózáshoz kötôdnek. Az első tengeri biztosításokat a tizenhatodik században kötötték; tengerentúli biztosítást először 1782-ben kötött egy angol cég. Hamarosan a londoni Lloyds vezetố helyet szerzett a kibontakozó biztosítási szakmában, és ezt a helyet már két évszázada tartja." (Giddens, 2000: 35)

Ez a kockázat-alapú jövốkép lassan elterjedt az egész társadalomban is és komplett rendszereket, sốt magát a kapitalizmus épületét húzták fel erre az alapra. De a modern intézmények, így például az egészségbiztosítás, az öregségbiztosítás és tulajdonképpen maga a későbbi jóléti állam egésze is csak egy kockázat-alapú jövôképbôl kiindulva érthetố meg. A modern világot kalkulálhatóvá, kiszámíthatóvá tették, a biztosítás révén pedig megszelídítették a veszélyt jelentô dolgokat is. A jövő gyarmatosítása elkezdődött. 


\section{Kockázattársadalom}

Attól azonban, hogy a kockázat fogalma megjelent, még nem beszélhetnénk kockázattársadalomról. Ehhez az ellenőrzött kockázatoknak először „el kellett szabadulniuk". A kockázatok teljes ellenôrizhetôségének a megkérdőjeleződésével lépünk át egy új korszakba, amelyet a szakirodalom kockázattársadalomnak nevez. Az ipari korszak racionális, kiszámítható világa észrevétlenül fordult át önmaga torzójába, irracionális, kiszámíthatatlan kockázattársadalommá válva.

A következôkben ezt az átalakulást vesszük alaposabban szemügyre. A kockázattársadalom elméletének megfelelően két fő szakaszt különítünk el: ipari- és kockázattársadalmat. Ezt követően megvizsgáljuk az átmenet jellegét, beszélünk a reflexivitásról (az átmenet elkerülhetetlenségéról) és meghatározzuk a kockázattársadalom fố területeit.

\section{A két fő szakasz}

Az ipari társadalmakat - így a kapitalista és az államszocialista társadalmakat egyaránt - jellemezte egyfajta, az egész társadalmat átható közös hit abban, hogy a haladás és a fejlődés előbb-utóbb minden problémát képes lesz kezelni. Hogy racionálisan, a technológia segítségével az emberi együttélés egy magasabb szintjén a Rossz a maga teljességében elúzhető - hogy kis túlzással néhány ezer évvel a földi Paradicsomból való kiűzetés után az ember a Technológia és a Tudás segítségével újból megteremtheti - de immár ő maga, saját magának - a Paradicsomot.

Ezt a hitet ebben a néhány száz évben - amíg az ipari társadalom felépítése folyt, és ezzel párhuzamosan a természetet, mint eszközt, mint meghódítandó és leigázandó környezetet állították be - nem kérdőjelezték meg tömegesen. Nem folyt vita a kérdésrôl - nem úgy, mint manapság. Ez volt a Közös Alap. Eretnekség lett volna a hiányosságait felhánytorgatni.

A mégis kételkedőket értetlenkedés fogadta és a „racionális” válasz, hogy a fejlődés idôvel majd minden problémát megold. A haladásban való hit tekintetében nem volt különbség kapitalista vagy szocialista társadalom között, hisz mindkettő ipari és modern volt. Ez a fejlődésbe vetett modern hit szinte az „egykori” (premodern) vallásosság helyébe lépett. A modern ember a haladást, a fejlődést és a technológiát választotta, mint saját hitet, mint választ minden végsố kérdésre - szemben a kozmikus Istennel. ${ }^{5}$ Ezzel azonban végképp elveszítette a helyét a természetben, amit hosszú évezredek során a vallás segítségével ő maga teremtett - csakhogy ennek a „hibának" a felismeréséhez évszázadoknak kellett eltelnie. Amikor pedig ez a felismerés tömegessé vált, akkor már jócskán benne éltünk a kockázattársadalomban.

A kockázattársadalom elmélete tehát két fó szakaszt különít el:

1. Az iparit: az ipari társadalmakban minden kockázatot ellenóriznek, vagyis egyfajta végsố határértékként arra törekszenek, hogy a jövő́ben minden kockázat kiszámítható legyen, tehát a rendszer inherens (önmagából fakadó, önmaga tartalmazta) része. Épp ezért az ipari társadalmakban a kockázatokról, a fejlődés káros mellékhatásairól nem folyik igazán nyilvános vita, hiszen kezelésük-ellenőrzésük mindig sikeresként van feltüntetve. De ha valamit 
mégsem sikerülne megoldani a jelenben, akkor a fejlődés a jövőben ezt a hibát is kiküszöböli.

2. A kockázattársadalom: az ellenórizhetetlen kockázatok kerülnek a nyilvános vita középpontjába, kiszorítva onnan a fejlődéshit alapján konstruálódó párbeszédeket. Vagyis újra elôtérbe kerül, hogy a fejlődésnek ára van, és ez lassacskán meghatározza a politikai viták, döntések egy jó részét is. ${ }^{6}$

\section{Átmenet a kockázattársadalomba}

\section{Külső kockázałok helyett gyártołt kockázatok}

Míg a premodern társadalmakra a kívülrôl jövő kockázat volt elsősorban a jellemzô, addig napjainkra ez jelentősen megváltozott és a kockázatokat mi magunk állítjuk elő, vagyis belülrôl fakadnak.

A külsố kockázat versus belsố (gyártott) kockázat az átmenet egyik legfontosabb jellemzője. A korábbi korok embere elsősorban a rossz időjárástól félt, az ebből fakadó éhínségektôl, a földrengéstôl, a tengeri viharoktól... Vagyis számára a természetnek való kiszolgáltatottság, az előre nem látható természeti katasztrófa jelentette a legnagyobb kockázatot. ${ }^{7}$

A kockázattársadalomban élố embert ezzel szemben a saját maga által létrehozott kockázatok fenyegetik, sokszor úgy, hogy errôl tudomása sincs. Az átmenet persze a természetből fakadó kockázatok sem tűnnek el, de jelentőségük csökken, illetve jellegük is megváltozik: a természet leigázása folytán előálló anomáliák - üvegházhatás, vízszennyezés, ózonlyuk... - már nem a hagyományos értelemben vett természeti kockázatok, ugyanis ezek is egyre inkább a rendszeren belülről, nem pedig kívülrôl származnak. Tulajdonképpen minden egyes új emberi találmánnyal feltalál(t)unk egy új kockázatot is és ezzel hatással vagyunk a természetre, mégpedig előre ki nem számítható módon.

Természetesen e megkülönböztetés a két korszak között egy fokozatos átmenetet feltételez, ahol a hangsúly a külsố kockázatokról lassan a belsôkre tevődik át. A korábbi korszakban is voltak belső, az emberek együttéléséből fakadó veszélyek. Ezek közül például a túzvészek, illetve a részben emberi, részben természeti okokból pusztító járványok voltak igen veszélyesek. Azonban két ok miatt mégis megállapítható a korszakok közötti alapvetô különbség:

1. Korábban a belsô kockázatokkal többnyire tisztában voltak az emberek. Vagyis tudták, hogy ezek veszélyt jelentenek, épp ezért a korábbi tapasztalatok alapján lehetséges volt felkészülni a kezelésükre - például kiépítették az állandó tűzoltóságot, vagy járványügyi hatóságot hoztak létre. Az új természeti és belsố kockázatok természete viszont nem ismert, soha korábban nem találkozhattunk velük. Abban sem lehetünk biztosak, hogy mi az, ami veszélyekkel jár, és mi az, ami nem.

2. Másrészt a két korszakban eltérố a kockázatok egymáshoz való aránya: bár korábban is voltak belsố kockázatok, de ezek száma és előfordulása jóval kisebb volt, mint a külső kockázatoké, vagy a későbbi belső kockázatoké. 


\section{A normarendszerek csődje}

A belső kockázatok elburjánzásával felszínre került a normarendszerek csődje is - ami az átmenet második legfontosabb jellemzője. A fejlődéselvú norma ugyanis evidenciaként kezeli, hogy a technológia jó, hogy a döntések helyesek és a fejlődés folyamatos. Ezzel szemben viszont azt látjuk, hogy a hasznos döntések károkat okoznak, a technológia nem kívánt mellékhatásokkal jár és ezek a mellékhatások gyakorta jóval nagyobbak, mint maga a kívánt hatás.

A kockázattársadalom elmélete szerint tehát a jó döntések - rossz eredmény metódusa megkérdőjelezheti a fejlődésbe vetett hitet, rámutatva annak ellentmondásosságára.

\section{Az ellenőrizhetőség teljes megkérdőjeleződése}

Végül ez az átmenet elvezet a kockázat központi mozzanatának, a kalkulálhatóságnak, a kiszámíthatóságnak és az ellenőrizhetőségnek a végéhez is. Egyrészt nem tudjuk, mit kell ellenôrizni, vajon mi az, ami veszélyes. Másrészt, még ha tudjuk is, hogy valami veszélyes lehet, sokszor a belső, gyártott kockázatok természete nem ismert, nem tudjuk, hogy vajon, amit teszünk, azzal segítünk, vagy netán ártunk.

Végeredményben el kell ismernünk, hogy nem tudunk mindent ellenőrizni, sôt még azoknak a folyamatoknak a pontos lefolyását sem garantálhatjuk, amelyeket mi magunk indítottunk el.

\section{Az észlelés-tudatosulás-elfojtás kérdése}

Az új, a kockázattársadalomba való átmenetból fakadó problémákkal való szembenézés mindig nehéz. Az egyik leggyakoribb stratégia, hogy az emberek a homokba dugják a fejüket, és úgy tesznek, mintha semmi sem változott volna - vagyis ugyanúgy élik az életüket, mint addig. Persze az elfojtásnak, a kockázatok elkendôzésének kulturálisan és társadalmilag meghatározott technikái (intézmények-cselekvésformák stb.) is léteznek.

A kockázattársadalomba való átmenetnek csak az egyik oldala az újfajta kockázatok megjelenése. Ugyanilyen fontos, hogy ezt idôvel felismerjük. Tehát a kockázattársadalmat - ellentétben az ipari korszakkal - folyamatos viták jellemzik arról, hogy mi az ami veszélyes, s azt hogyan lehet kezelni, ezért az észlelés-tudatosulás-elfojtás kérdésköre a középpontba kerül.

Mindennek a hátterében az áll, hogy nincsenek egyértelmú válaszok. Nem feketén-fehéren - mindenki számára nyilvánvalóan - egyértelmú, hogy mi a probléma, milyen annak a természete és hogyan kell azt kezelni. ${ }^{8}$ Részben ebból fakad, a korábbiakhoz képest, most már tömegesen elvitatják a politikusoktól és a tudósoktól a kizárólagos jogot, hogy értelmezzék a szituációkat és aztán döntsenek arról, hogy mit kell tenni. 


\section{A biztosíthatóság vége}

Legvégül, az átmenet során bizonyos területeken megkérdőjeleződik a biztosíthatóság is. Vagyis, ha valaminek a kockázata kiszámíthatatlan, a bekövetkező károk pedig felmérhetetlenek, akkor értelmetlen biztosításról beszélni. A biztosítótársaságok már nem kerekítik egészre a világot azzal, hogy egy bizonyos összeg befizetése esetén a rendkívül valószerütlen bekövetkezése esetén is helyrebillentik a rendszert - tehát nem kártalanítanak. Végeredményben a kockázattársadalomban a kalkulálható kockázatok száma csökken, és garmadával jelennek meg a bizonytalan veszélyek.

\section{Reflexivitás}

No de muszáj nekünk kockázattársadalomban élni? Mi történik, ha nem hagyjuk, hogy a kockázattársadalomba való átmenet megtörténjen?

A kisebbik probléma ezzel a felvetéssel az, hogy kései. Amikor ez a kérdés először felmerült - jó pár évvel ezelőtt - már kockázattársadalomban éltünk. A nagyobbik probléma, hogy a kérdés hamis, mert azt a látszatot kelti, mintha valójában lehetôségünk volna eldönteni, hogy a kockázatok és a veszélyek milyen jelleget öltsenek.

Az elmélet válasza erre a kérdésre az, hogy a két szakasz - az ipari és a kockázattársadalom - közötti átmenet reflexív. Ez tulajdonképpen több dolgot jelent egyszerre:

1. Az átmenet reflex-szerú, a „fejlődés” nem szándékolt következménye.

2. Nem opcionális, tehát nem választás eredménye, nem tudatos.

3. Az átmenet önkonfrontációt jelent: annak a felismerését, hogy a problémák már nem kezelhetốek a régi, modern logikával.

A kockázattársadalom létrejötte voltaképpen akár mellékhatásnak is tekinthetô: a modern ipari fejlődés nem szándékolt következménye, ami a kultúra és a társadalom teljes átalakulását eredményezi.

A kockázatok elszabadulása a „fejlődéssel” járt, mi magunk hoztuk létre a kockázattársadalmat, miközben a tökéletes, biztonságos, kockázatmentes(!) ipari társadalmat akartuk felépíteni. Tehát éppen, hogy a szándékaink ellenkezójét értük el, tökéletlen, nem biztonságos és kockázatokkal terhelt rendszert alakítva ki. Az általunk gyártott és használt technológia, az ellenôrzésünkön kívüli folyamatokat indított el. A kulcsmozzanat az, amikor ezt felismertük. Amikor ráébredtünk, hogy a hagyományos módon, még több, újfajta technológiával ez a probléma már nem kezelhetô.

A kockázattársadalom tehát felveti a kezelhetôség kérdését: vajon képesek vagyunk-e megbirkózni ezzel a kihívással? A kérdés arra mutat rá, hogy tulajdonképpen még most is egy olyan világban élünk, ami technológia és tudás-alapú. Ennek a világnak az intézményeit az indusztriális korban és annak a vezénylésére hozták létre az elődeink. Vagyis miközben a keretek a régiek maradtak, közben a problémák, amelyeket orvosolni kell, immár újak. Az információs korszaknak épp ezért az egyik legfontosabb kérdése az, hogy képes lesz-e ezeket az intézményeket úgy megújítani, hogy ezzel a konfliktussal sikeresen szembe tudjanak nézni. 


\section{Információs társadalom, mint kockázattársadalom}

Az ipariból a kockázattársadalomba való átmenet végső eredményképpen ott állunk pôrén azokkal a folyamatokkal szemben, amelyeket mi magunk indítottunk el, de egyre kevésbé tudjuk kordában tartani ôket a racionális, technológiai fejlődés talapzatán. Hogy miért? Jean Baudrillard szavaival: „Egy valami biztos: a kiindulási adatok összetettsége, minden hatás potenciális megfordíthatósága folytán a racionális beavatkozás semmiféle formájának az illúziójába nem ringathatjuk magunkat. Azzal a folyamattal szemben, amely messze meghaladja a közremúködők egyéni és közös szándékát, kénytelenek vagyunk elfogadni, hogy a jónak és rossznak mindennemú megkülönböztetése (és így esetünkben annak lehetôsége, hogy pontos mércével ítéljük meg a technológiai fejlődést) szigorúan csak racionális modellünk legalsó szélén érvényes - e határokon belül az etikáról lehet gondolkodni és gyakorlati meghatározás lehetséges -, ezen túl, annak a folyamatnak az egészét tekintve, amelyet magunk indítottunk el, és amely már nélkülünk folytatódik egy természeti katasztrófa könyörtelenségével - szerencsénkre vagy szerencsétlenségünkre -, a jó és a rossz elválaszthatatlansága uralkodik, tehát olyan helyzet, amelyben nem lehet az egyiket a másik nélkül előmozdítani. Ez pontosan az elátkozott rész teorémája, és teljesen fölösleges azt kérdezni, hogy ennek így kell-e lennie: így van, és aki ezt nem ismeri föl, a legnagyobb önámítás csapdájába esik. Ez nem mond ellent annak, amit az életünk etikai, ökológiai, gazdasági szférájában tehetünk, de teljességgel relativizálja a jelentôségét szimbolikus síkon, vagyis az elrendeltetés síkján." (Baudrillard, 1997: 91, kiemelés az eredetiben)

„Magyarra” fordítva: a kockázattársadalom tehát azt jelenti, hogy egy igen paradox szituáció állt elô: a mai „fejlôdésben” a még több jó, automatikusan egyenlő a még több rosszal. Ezt nyugodt szívvel nevezhetjük a kockázattársadalom kvintesszenciájának is.

A fejlődést ellenôrizni, irányát bejósolni, folyamataira hatással lenni, csak nagyon szúk keretek között lehetséges - pontosan addig, ameddig racionálisnak tételezzük fel. Ez a modell azonban igencsak leszúkít. A fejlődés irracionális, a racionalitás irracionalitást szül, a technológia további problémákat okoz és a megoldás még több technológiáért kiált. A beavatkozások pedig összeütköznek egymással, a racionális jócselekedetek össztársadalmi, vagy összgazdasági szinten összeadódnak és nem szándékolt következményként képesek az eredetileg kívánt hatást a másik végletébe, a rosszba átfordítani.

Mi köze van azonban ennek az információs társadalomhoz? Látszólag semmi. Valójában azonban mind a két elmélet - a kockázattársadalom és az információs társadalom elmélete is központi helyen szerepelteti a modern technológiát, sôt, mint látni fogjuk, tulajdonképpen ugyanarról szól a két elmélet, csak másképp.?

\section{Az információs társadalom: a bizonytalanság kiterjedése}

Az információs társadalom az emberi együttélés új módja, ahol az információ hálózatba szervezett előállítása, tárolása, terjesztése, feldolgozása... játssza a legfontosabb szerepet. Attól új ez az együttélési mód, hogy minőségileg is megváltoztatja az 
emberek közötti társadalmi viszonyt - azaz a társadalom együttélésének megváltozik a megszokott rendszere. Mindennek a hátterében az infrastruktúra, az új információs és kommunikációs technológia áll. Ez az 1960-70-es évektôl kezdett elterjedni, a kapitalizmus akkori megújulásával párhuzamosan, ami létrehozta a globális, információs gazdaságot és ennek legfốbb szervezeti alapját, a hálózatot. ${ }^{10}$ Mára a hálózat vált a gazdaság domináns formájává, amely a nap 24 órájában múködik, felülírva a korábbi napi életritmust. A hálózat kettéosztja a világot a számára értékesekre és értéktelenekre, csak azt foglalva magába, ami és aki fontos-értékes a számára - ezzel egy újfajta globális geometriát teremt, a korábbi gazdaságföldrajz szabályait átalakítva.

A gazdaság hálózati alapú szervezôdése minden más társadalmi területre is hatással van. Ez az új hálózati elrendeződés elsôsorban a lokális, helyhez kötött közösségi identitással kerül szembe, valamint az ezen alapuló társadalmi intézményekkel így például az állammal. Az emberek válasza erre az összetett kihívásra rendkívül sokszínú - de különösen szembeötlő a (globális) társadalmi mozgalmak elszaporodása az információs korszakban. Egy részük védekezô alapon elutasítja a változásokat, míg más részük megpróbál aktívan hatni a változás irányára, és radikálisabban fellépni egyes folyamatokkal szemben.

Az információs társadalmi változások legfontosabb hatása, hogy a társadalom egészében megnő a bizonytalanság, a biztonság hiánya, a bejósolhatatlanság. A globális gazdasági- és médiahálózatok rugalmasságát ugyanis nem képesek teljes egészében átvenni az emberek, akik saját értékrendszerük, normaviláguk alapján élnék az életüket, ha azok képesek volnának zökkenômentesen múködtetni a körülöttük lévố világot. ${ }^{11} \mathrm{Ez}$ az újonnan kialakuló világ ugyanis az embertôl is megkövetelné a flexibilitást és a rugalmasságot. Ugyanakkor az emberi társadalmak struktúrája bizonyos nehézséggel reagál az újdonságokra. A már kialakított intézményeknek van egyfajta tehetetlensége - ami egyébként a stabil múködésükhöz részben elengedhetetlen is.

Így, ami korábban biztos pontot jelentett (elsôsorban a fejlett világban) - a család, a gyerekek, az otthon, a munka, a (viszonylagos) jólét, a politika, az állam... mind-mind „megbolondul", kifordul a sarkaiból, és bizonytalanná válik a léte. Ez az új súlytalanság állapota, ahol megkérdőjeleződik a társadalmi szolidaritás és növekszik az ember magárautaltsága.

\section{Információs társadalom = kockázattársadalom}

Bár elsôre nem látszik, az információs társadalom növekvố szociális bizonytalansága és a kockázattársadalom bejósolhatatlan világa megegyezik. Egy és ugyanazon dologról szólnak - csak más fogalmakkal ragadják meg azt. Az információs társadalom maga a kockázattársadalom - errốl könnyen meggyőzốdhetünk, ha megpróbáljuk az információs társadalmakat a kockázattársadalomra megalkotott fogalmakkal leírni:

1. A gazdaság elszakad a valós alapoktól és a technológia segítségével szétfeszíti az együttélés korábbi rendszerét.

2. Az állam elveszíti az ellenôrzố és fékezô szerepét, a globális hálózatok túlnyúlnak a határain.

3. A demokratikus politika válságba kerül, mert nincsenek jó vagy rossz döntések, egyszerre hat mind a kettő - miközben a szakértốk bizonyossága is véget ér. 
4. A társadalmi vita középpontjába a fejlődés jellege, a fontos célok és a megengedhetố eszközök kérdése kerül.

5. Az emberek a kollektív normák előírásai helyett saját maguk kell, hogy identitást válasszanak, hogy közösséget találjanak, választ a kialakuló szituációkra.

6. Az embereknek meg kell tanulniuk élni, és együtt élni a kockázatos szabadsággal, valamint azzal, hogy mások döntései a veszélyek vállalásáról meghatározhatja az életüket.

Ebben a folyamatban immáron nem csak a javakat kell szétosztani, hanem a „rosszak”-at is. Vagyis meg kell mondani, hogy ki az, aki valószínúleg pórul jár - „természetesen” többnyire a rosszabb érdekérvényesítő képességgel rendelkezô szegényebb régiókról, csoportokról van szó.

Az információs társadalom maga a kockázattársadalom. Egy idóben, egyszerre, és ugyanolyan módon, észrevétlenül alakultak ki, az ipari korszakban élôk cselekvéseinek sajátos és nem várt összegződéseként. Mind a kettô azt mutatja, hogy „így már nem mehetett tovább". Ennek következtében először szinte teljesen észrevétlen, majd később egyre nyilvánvalóbb módon az ipari társadalom túllépett önmagán.

Egyáltalán nem biztos azonban, hogy az ipari korszak ellentmondásainak a „meghaladása” sikerül. A túllépéshez ugyanis két dolognak kellene megváltoznia:

1. Új intézményrendszer: kérdés, hogy az ipari korszakra következő új, információs korszakban hosszútávon is megmarad-e a bizonytalanság magas szintje, vagy sikerül olyan új intézményrendszert létrehozni a mostani, válságban lévő, ipari társadalomban gyökerező szisztéma helyett, amely képes menedzselni a felmerülő új gondokat. Így például megújítani a nemzetállamot, a jóléti rendszert, a demokráciát, a családot és a munka világát.

2. A másik, ennél is fontosabb kérdés azonban, hogy az ipari társadalom technológia- és tudásorientált problémakezelését sikerül-e megváltoztatni? Az információs társadalom is kapitalista rendszer, célja a hatékonyság, a profit termelése és a versenyképesség növelése. Épp ezért a technológiával kapcsolatos attitûdök és az alapvető kapitalista célok megváltozása csak akkor lehetséges, ha egy olyan megújult társadalmi intézményrendszer - és mögötte egy újfajta kultúra - jön létre, amely képes a globális gazdasági „túlpörgést", a fékevesztett láncreakciót kordában tartani. Tehát a technológia kezelése nagyban függ az első tényezőtől, az új intézményrendszer kialakulásától.

Ebben az értelemben az információs társadalom és a kockázattársadalom ugyanaz, hisz ugyanazokat a kérdéseket teszi fel a társadalom és a gazdaság „fejlődése” kapcsán.

\section{Forgatókönyvek - a változás lehetséges irányai}

Arról, hogy az információs társadalom vajon tud-e lényeges változásokat is hozni a társadalommal való együttélés, a kapitalizmus haladáselvűsége, és a technológia használata kapcsán, megoszlanak a vélemények. 


\section{Pesszimista forgatókönyv: úifajta kockázatok a láthatáron}

\section{A hibridekről}

A Természet és a Társadalom kettéválasztása a modern korban azt eredményezte, hogy elfedtük a kézenfekvôt: minden, amit a társadalomban teszünk, hatással van a természetre is. Így bár állandóan olyan dolgokat hozunk létre, amelyek hibridek: egyszerre természetiek és társadalmiak is, rögvest úgy teszünk, mintha ez meg sem történt volna. A hibridekben azonban nem lehet teljesen kettéválasztani a két szférát. Az eredmény hálózatokban burjánzó hibridek. Latour terminus technicusa - a hibrid - a természet és a társadalom (kultúra) kusza és folyamatos összekeveredését jelenti: „A kultúra és a természet egésze kavarodik össze nap mint nap. [...] Nyomjuk csak meg a legártatlanabb aeroszol spray gombját, és máris úton vagyunk az Antarktisz felé, ahonnan Irvine-be jutunk, a University of Californiához, majd a lyoni hegyláncokhoz, a nemesgázok kémiájához és végül talán az ENSZ-hez, de ez a vékony szál annyi darabra szakad, ahány tiszta diszciplína csak van." - îrja Latour egy újságcikkben elốforduló logikai láncolat kapcsán. (Latour, 1999: 13)

Vagyis az aeroszolos spray megnyomása rögvest az ózonlyukra, az azt kutató tudósokra, majd a káros hatásoktól szenvedổ hegyláncokra, a káros mechanizmus kémiai összefüggéseire és végül az államok közös összefogásának a szükségességére mutat. Tehát, bár a természetet megpróbáljuk kizárni a világunkból, ez mégsem sikerül teljesen, újra és újra betüremkedik oda, összekeveredik a társadalommal-kultúrával - s így állandóan hibrideket hozunk létre.

Ugyanakkor minden mindennel összefügg: ezt jelenti a hálózat. Mozdíts csak meg egy szálat itt, és valaki jóval messzebb jelezni fog, hogy változás érte. Ez pedig egyre erôsebb lesz, nem sikerül a burjánzást - a társadalom és természet összekeveredését csökkenteni, miközben mégis folyamatosan kísérletet teszünk arra, hogy megkülönböztessük ôket egymástól. Ezért szabdaljuk fel a hibrid hálózatát darabokra az egyes látásmódok, tudományok, technológiák stb. mentén. Így azonban elvész annak a lehetôsége, hogy egészbe tudjuk összerendezni a világot, hiszen azt a részeire daraboltuk fel.

\section{Új információs kockázatok}

Az információs társadalom, mint kockázattársadalom annyiban változtat ezen, hogy a már fentebb említett módon az Ökocídium - a természet kiirtása -, mint a modern kor központi kockázata mellett, a természet és a társadalom határáról részben a társadalom és virtualitás határára helyezi át a kockázati forrásokat, vagyis a hibridek hálózatos burjánzása immáron nem csak a természet és a társadalom, hanem a társadalom és a virtualitás határán is lehetségessé vált.

Az új információs társadalmi kockázatok egyrészrôl a már hagyományos közegben, a természet és a társadalom határán termelődnek. Másrészrôl viszont, ami új, hogy térben és időben nem korlátozható, belsố, a rendszerben gyártott - csak az információs társadalomra jellemző - kockázatok jelennek meg: 
1. A régi logikával megérthetô - a természet és a társadalom határán termelődő új, gyártott információs kockázatok. Például: a mobiltelefónia, az egyéb káros sugárzások (pl. monitoré), a veszélyes hulladékok megsokszorozódása (akkumulátorok, képcsövek, üres festékpatronok, nehézfém tartalmú kimustrált alkatrészek stb.), az energiaszükséglet megsokszorozódása, a papírhasználat megváltozása stb.

2. Az új logika mentén - a társadalom és a virtualitás határán - termelôdố újfajta kockázatok. Például: a Y2K (vájtuki: a kétezredik dátumváltás hisztériája), az adatvesztés, a számítógépes vírusok és az elektronikus támadások stb.

A pesszimista forgatókönyv szerint tehát az információs társadalom nem képes túllépni az ipari társadalom technológiai ellentmondásain, sôt még tetézi is a problémát azzal, hogy újfajta, sajátos információs kockázatokat hoz létre. Mindezen felül úgy tûnik, hogy nincs reális esély egy új intézményrendszer kialakulására sem.

\section{Optimista forgatókönyv: új üdvtan?}

Nagy fantáziával elképzelhető ugyanakkor egy optimista forgatókönyv is, ami Baudrillard pesszimizmusával dacolva azt állítja, hogy az információs társadalom igenis képes lehet egy új megváltás feltételeinek „kitermelésére”.

Vagyis Baudrillard szavaival élve azt mondhatjuk, hogy szimbolikus síkon - az elrendeltetés síkján - maradt még hely az elkárhozáson kívül egy újfajta üdvtannak is. Persze kérdés, hogy tényleg lehetséges-e, hogy az emberiség hosszú távú kilátásai radikálisan javuljanak, vagyis hogy együtt tudjunk élni a természettel és önnön teremtményeinkkel?

Ez a kérdés csak látszólag tûnik újnak. Az információs társadalom és a kockázattársadalom azonosságát a hasonló kérdésfeltevésen túl közös keletkezésük is mutatja: mindkettố ugyanakkor, ugyanabból az ellenkultúrából táplálkozva, majd a kapitalista gazdaságtól sajátos „gellert” kapva jelenik meg a napjainkban.

Ez a közös eredet arra is rámutat, hogy kezdetben az új technológia pontosan az ipari korszak logikájával szemben, azt megújítandó jelent meg! De a PC, a személyi számítógép forradalmának az elindítói az 1960-70-es években olyan „alvajárók” voltak, akik korántsem tudták, hogy mit is cselekszenek valójában. Ugyanakkor mégis hittek az akkori ellenkultúrában, ami Amerikát belengte: „Az egyik résztvevô-megfigyelő, Jim Warren szavaival: „stílusuk genetikai kódja a hatvanas években alakult ki, a társadalmielit-ellenes, háborúellenes, szabadságra vágyó, fegyelemellenes magatartásformából.” A fiatal számítógépesek munkájára jellemzố komputer- és információfelfogás furcsa ötvözete volt a politikai lázadásnak, a tudományos fantasztikumnak, a csináld-magad mozgalomnak, és a puszta játékosságnak.” (Roszak, 1990: 243, Freiberger es Swaine nyomán). Vagyis a személyi számítógép részben ugyanabból a kultúrából táplálkozott, mint a harcos környezetvédelem, a feminizmus, a demokrácia megújítási mozgalma és a szexuális forradalom.

Amiért azonban mégiscsak egy új üdvtanról lehet beszélni, az az, hogy kezdetben ezeknek a számítógépeseknek a lelkesedése ötvözte a technofóbiát és a technofíliát - vagyis egyszerre voltak az iparosodott társadalmak technológiaorientáltsága 
ellen, tehát elutasították a modern technológiát, másrészrôl viszont üdvözölték a számítástechnikát, mint amely képes az ipari logikán felülkerekedni. Ezen ellentmondó elvek integrálása szerint az új technológia nem törekedne a természet erôi fölötti uralomra, sốt, a társadalom szerves megújulásához is elvezethet, új közösségi alapon épülő demokráciát kialakítva.

Ebben az értelemben a posztindusztrialista jövő - a mi információs jelenünk az 1970-es évekbôl nézve az ígéret földjének tûnt, ahol az ipari társadalmak minden búne feloldozást nyerhet, ahol minden tiszta lappal, a természettel harmóniában újrakezdhető. Egy az 1960-as évek végéből származó vers így fogalmazta meg ezt az életérzést:

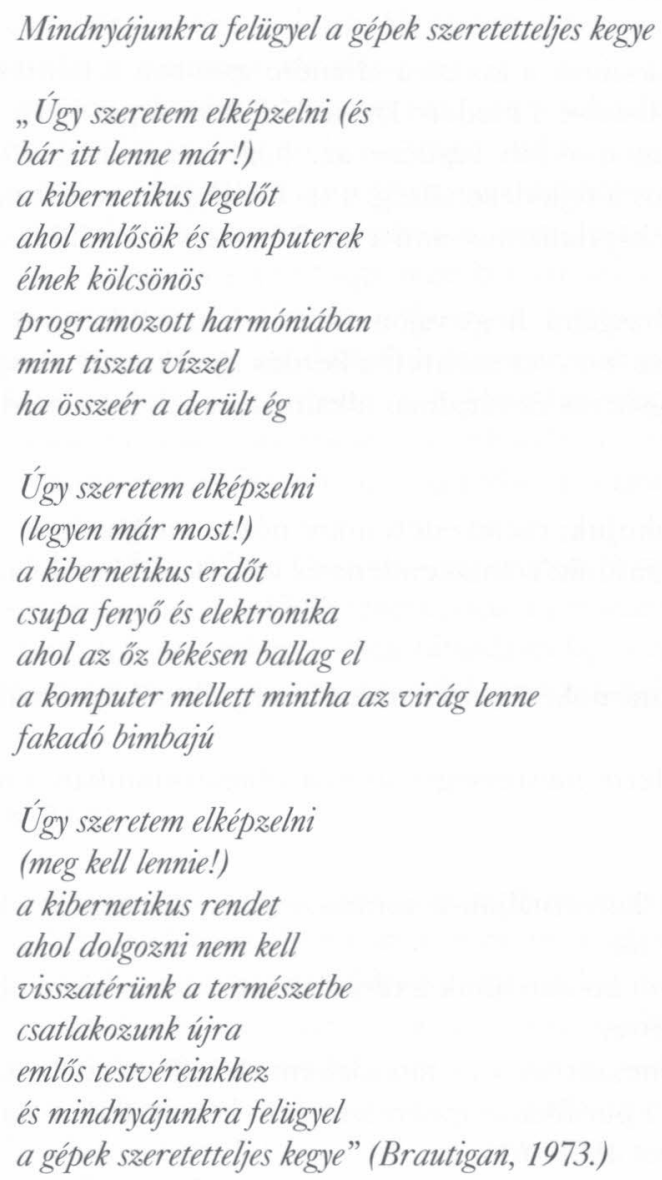

Tehát ebben az ellenkulturális közegben - bár a benne élők számára nem kristálytisztán, de - egybecsúszott a technika és a természet szeretete. A probléma azonban az, hogy a valóságban mégsem volt képes néhány kommunán kívül igazán más, tartós alternatívát felmutatni, még ha - mint tudjuk - ennek az ellenkultúrának óriási hatása is volt, és végeredményben elvezetett a mai, információs korszakba. Úgy tûnik ugyanis, hogy egy, a természetet és technológiát összebékítő ellenkultúra cél- 
kitûzéseinek most is volna alapja a társadalomban. A sikertelenség mögött a gyermeki elképzelések tarthatatlansága húzódott. Ismét csak Roszakot idézve: „Az ellenkultúra számos képviselôje azonban úgy képzelte, hogy az ipari csúcstechnika eredménye az lesz, hogy a törzsi demokráciában élő lakosság szarvasbốr ruhákba öltözve bogyókat fog gyújtögetni az erdőn” (Roszak, 1990: 254)

Az ellenkultúra jövőjét - ez volna a mi múltunk - azonban ismerjük: kommercializáció és a kapitalista gazdaság néminemú, nem túlzott átalakulása. Manapság pedig már lázadni is divat.

\section{Mit is jelent modernnek lenni?}

Az ellenkultúra naiv elgondolásainak a kudarca ellenére azonban a kérdés továbbra is ott marad: vajon meghaladható-e a modern kor fejlődéselvúsége? Ezek szerint az információs társadalom legfontosabb kérdése az, hogy meghaladható-e a modernitás. Létezhet-e kapitalizmus a fejlődéselvúség, a technológiába vetett hit és a modernség mítosza nélkül? Olyan kapitalizmus, ami a mai túzokért nem áldozza fel a holnapi verebet.

A válaszhoz először meg kell vizsgálni, hogy vajon mit is jelent modernnek lenni. A már idézett Bruno Latour egész könyvet szentelt a kérdés igen kreatív vizsgálatának. Szerinte három paradoxon együttes és rugalmas alkalmazása jelenti a modernséget:

„Elsô paradoxon

A társadalmat szabadon alakítjuk; cselekedeteinkre nézve immanens.

A természet nem a mi alkotásunk; transzcendens és végtelenül hatalmasabb nálunk.

Második paradoxon

A társadalom nem a mi alkotásunk; transzcendens és végtelenül hatalmasabb nálunk.

A természetet mi hozzuk létre mesterséges úton a laboratóriumban; immanens.

Harmadik paradoxon

Az elsố garancia: noha mi konstruáljuk a természetet, a természet olyan, mintha nem mi hoznánk létre.

A második garancia: noha mi konstruáljuk a társadalmat, a társadalom olyan, mintha nem mi hoznánk létre.

A harmadik garancia: a természetnek és a társadalomnak teljességgel szétválasztottnak kell maradnia: a purifikáció gyakorlata nem keveredhet a transzláció gyakorlatával." (Latour, 1999: 61)

Vagyis a modernek hatalma a folyamatos kettőségben rejlik, hogy egyszerre képesek mozgósítani a társadalmat és a természetet: „szabadon teremtik és pusztítják társadalmukat, miközben törvényeit elkerülhetetlenné, szükségszerûvé és abszolúttá teszik. [...] a modernek mindig is két vasat tartottak a tûzben. Legyôzhetetlenné váltak." (Latour, 1999: 70-71) 
Latour arra hívja fel a figyelmet, hogy a modernek olyan szabályokat alkottak, amelyek kreatívan áthághatóak, szabadon értelmezhetőek és lehetôvé teszik, hogy a társadalom, illetve környezete szabadon alakítható legyen. Így hihetetlenül nagy előnyre tettek szert mindenki mással szemben - akiket kötött a természet tisztelete, az ôsök tradíciói, a vallás és ezernyi más béklyó. Ezeket a népeket premodernnek nevezték el.

Ez az idilli állapot azonban napjainkban kezd véget érni: a természet és a társadalom szinte tökéletes szétválasztása, valamint folyamatos újbóli összekeverése egyre tarthatatlanabbá válik. A kreatív pusztítás - újrateremtés - tempója már sem a társadalom, sem a természet számára nem elviselhetô többé. Ettôl persze még egyáltalán nem biztos, hogy ez az évszázados logika meghaladható volna - ahhoz túlságosan is erôs rendszert hozott létre. Meglehet, hogy ez a rendszer könnyebben pusztítható el, minthogy sikeresen megújuljon.

Ennek ellenére talán nem kell teljesen kétségbe esni. Ahogy Manuel Castells az információs korszakról szóló trilógiája első kötetének a végén jelzi, van remény a természet és a társadalom között egy új kapcsolat kialakítására. (Castells, 1996: 477 478) Bár lehet, hogy ez nem egészen olyan lesz, mint amilyet a környezetvédók szeretnének. Castells szerint egy tágabb történelmi összefüggésben a hálózati társadalom az emberi együttélés egy teljesen új módja. Az emberiség kezdetén a természet uralta az embereket, majd késóbb az ész nevében megpróbálták legyôzni a természetet, felszabadulni a természet alól. Most belépünk egy új korszakba, amikor egyszerúen a kultúra már csak önmagára reflektál, mivel a természeten kívüli. A természet mesterségesen megő́rzendő dologgá vált, a természetet ideális kulturális formaként teremtjük újjá.

Épp ezért - állítja Castells - azt is mondhatjuk, hogy a történelemnek nincs vége, sőt, csak most kezdődik igazán, hisz a társadalmi fejlődés olyan fokra ért, ahol először élhetünk egy teljesen csak társadalmilag meghatározott világban. Ez az új létezés kezdete, az információs korszaké, amely a kultúra önállóságát hozza magával.

\section{Befejezés}

Várnunk kell. Ma még nem igazán látni, hogy az információs társadalmi változások okozta bizonytalanság, illetve az intézmények válsága inkább egy nagyobb kizökkenés, vagy valamifajta összerendezốdés kezdete-e. Végeredményben most úgy túnik, hogy az információs társadalom csak új kockázatokat, kockázati rendszereket termel, de valójában nem oldja meg a korábbi ipari kockázatok problémáit. Vagyis az ember természeti környezettel való termelési-együttélési konfliktusa nem szűnik meg az információs társadalom létrejöttével. Legfeljebb úgy tehetünk, mintha a természet kizárható volna az életünkből - ettől azonban még nem szűnnek meg a természeti konfliktusok.

Mindezek miatt az információs társadalom egyúttal kockázattársadalom is: beláthatatlan, kiszámíthatatlan és bejósolhatatlan. 


\section{JEGYZETEK}

1 Ezúton szeretnék köszönetet mondani Benda Klárának, Kolin Péternek és Z. Karvalics Lászlónak egy korábbi szöveg-verzióhoz fúzött értékes megjegyzéseiért, illetve az Információs Társadalom és Trendkutató Központ munkatársainak, akik egy parázs vitában járultak hozzá az anyag formálódásához.

2 Mint azt már megszokhattuk, nálunk magyaroknál minden másképp van. Míg a legtöbb nép nyelvében a kockázatra a rizikó kifejezéssel utalnak - aminek semmi köze a kockához, a kockajátékhoz és ebből fakadóan a szerencséhez vagy a szerencsejátékhoz sem - addig mi, magyarok, köszönhetốen feltehetốen a nyelvújítóknak, a kockázat szót használjuk a jelenségegyüttes megnevezésére. Ez ne vezessen félre minket, ahol a kockázat szó megjelenik ebben a szövegben, ott mindenhol a következőkben meghatározott rizikó értelemben használjuk, és figyelmen kívül hagyjuk, hogy a magyar nyelvben a szó egyértelmúen a szerencsejátékban gyökerezik.

${ }^{3}$ Ez nem jelenti azt, hogy akkoriban ne lettek volna például kereskedők, akik bizony tudták, hogy egyik-másik úton tolvajok leselkedhetnek rájuk. Viszont az ilyen, a jövốbeli eseményeken múló életvitel - ami kalkulált is ezekkel a veszélyekkel - nem volt tömeges, csak nagyon elenyészố töredékét érintette a közösségeknek. Szemben azzal, ami késóbb a modern társadalmakban a kockázat fogalom tömeges elterjedését hozta.

${ }^{4}$ Fontos azonban hangsúlyozni, hogy kezdetben a vállalkozó elốrelátása és sikere, a racionalitása, a jövő kiszámíthatóságába vetett hite nem kevésbé irracionális talapzaton állt, mint a megelôzố korok emberéé. Ahogy azt Max Weber a Protestáns etika és a kapitalizmus szellemében (Weber, 1995) írja, a racionalitás hátterében egy vallásos meggyőződés állt, mégpedig az, hogyha valaki sikeres az üzleti életben, akkor az azt jelenti, hogy eléri a lelki üdvösséget is a halála után. Mivel mindenki sorsa eleve elrendelt, már a születése elốtt eldốl, hogy a mennybe, vagy a pokolra jut-e. Ezt azonban senki sem tudhatja az élete közben - csupáncsak fürkészheti. A gazdaságilag sikeres élet arra utalhat, hogy Istennek tetsző személyről van szó, aki üdvözülni fog, nem pedig elkárhozni.

Talán meglepó, hogy ezt mondjuk, de az irracionalitás a racionalitás mögött késôbb csak fokozódott, amikor a vallás és a Jóisten kikerült a végső mozgató szerepéból, majd a racionalitás önmagáért valóvá vált. Ezt a fajta „túlzott” racionalizációt figyelhetjük meg a modernitás késốbbi szakaszában, ami végsố soron irracionalitáshoz vezetett - a racionalitás egyfajta „vasketrecként" fogja már az őt kialakítókat.

5 Nem véletlen tehát az sem, hogy újabban, a kockázattársadalom beköszöntével megnő a vallásosság, a spiritualizmus szerepe is, hogy az emberek újra hisznek, vagy hinni akarnak valamiben.

De tulajdonképpen a modern korszakban folyó szekularizációval párhuzamosan is léteztek valláspótlékok, pont ilyennek tekinthetố a technológiába (pl. orvostudományba) vetett hit, vagy bizonyos szempontból akár a munkásmozgalom maga is.

${ }^{6}$ Persze fontos szem előtt tartani, hogy mind a két szakaszban léteznek kockázat-elfedố technikák - így ideológiák, rítusok vagy épp áltudományok. A lényeges különbség, hogy a második szakaszban mégis a diskurzusok középpontjába kerülnek a kockázatok.

7 Ugyanakkor persze az individuális, személyre-szabott kockázatok egy része ekkoriban is szociálisak volt - úgy, mint például egy zsarnok közösségvezető, háborúskodó szomszédok.

8 De nyájas olvasó, nehogy azt hidd, hogy mindez Téged nem érint. Minden egyes döntéseddel voksolsz valami mellett és valami ellen. Hogy mit reggelizel, hogy tusolsz-e reggel, hogy milyen WC-papírt használsz, hogy hogyan mész a munkahelyedre... 
" A kockázattársadalom inkább a technológia „káros”, nem szándékolt oldalaira hívja fel a figyelmet, az információs társadalom pedig elsősorban az információs és kommunikációs technológiára, illetve annak az elterjedésére és a társadalommal kapcsolatos sajátos kölcsönös viszonyrendszerére helyezi a hangsúlyt.

${ }^{10}$ Ezt a hálózat fogalmat és tartalmát ne azonosítsuk automatikusan az Internettel! Itt egy új szervezôdési- és múködési módról van szó, ami más, több, mint maga az Internet. A fogalom itt a castellsi-i értelemben vett hálózat-vállalkozás (network enterprise, Castells 1996: 151201) kialakulását és a gazdaság belső rendjének információs korszakban végbemenő átalakulását takarja.

${ }^{11}$ Még ha egyesek meg is próbálják az életvitelüket teljesen rugalmassá tenni és alárendelni a rendszerból fakadó elvárásoknak (pl. munkamániás yuppie menedzserek) ez sohasem sikerül tartósan és sorozatos konfliktusokat okoz. Persze a globális gazdasági- és médiahálózatok mindenkinek hatnak az életére, hol észrevétlen, hol pedig kézenfekvő módon.

Az állítás magva tehát az, hogy az emberek még ha akarják sem képesek a hálózat rugalmassági fokát elérni.

\section{IRODALOM}

Baudrillard, Jean (1997): Az energia sorsa. In A rossz transzparenciája. 87-91. p. Budapest, Balassi - BAE Tartóshullám - Intermedia.

Beck, Ulrich (1998): A kritikai elmélettól a kockázattársadalom önkritikájáig. In: Replika 31-32. 7791. oldal

Castells, Manuel (1996): The Information Age: Economy. Society and Culture, Volume I: The Rise of the Network Society.

Giddens, Anthony (2000): Kockázat. In Elszabadult világ. 31-45 p. Budapest, Perfekt Kiadó.

Kövér ludak fenyegetik a légi közlekedést. Index hír. 2001. december 18., kedd 11:28.

Latour, Bruno (1999): Sohasem voltunk modernek. Budapest, Osiris.

Ökotantrikus nôi rapperek a faipar ellen. Index hír. 2001. november 12., hétfő 10:29

Richard Brautigan (1973): All Watched Over by Machines of Loving Grace. In: The Pill Versus the Springhill Mine Disaster. New York, Dell/Laurel. Idézi Roszak, Theodore. 1990.

Roszak, Theodore (1990): Az információ kultusza, avagy a számitógépek folklórja és a gondolkodás igaz mürészete. Budapest, Európa.

Weber, Max. (1995): A protestáns etika és a kapitalizmus szelleme. Második, bôvített kiadás. Budapest. Cserépfalvi. 